\title{
Attitude of Parents, Teachers and Students towards Corporal Punishment
}

\author{
Dr. Mahesh Kumar Muchhal ${ }^{1 *}$, Arun Kumar²
}

\section{ABSTRACT}

This Paper examines corporal punishment in the current education system. During the Gurukul system of Education, the disciples were punished for their indiscipline and misbehavior. But the punishment was only confined to do some physical work and had no adverse effect on the physical and mental abilities of the child. In modern time period universalization of elementary education is the prime motive of our govt. But unfortunately this type of formal education makes the child more and unhappy. The reason behind this unhappiness is existence of corporal punishment in formal system of education. The purpose of the present study was to judge the attitude of parents, teachers and students towards corporal punishment. For this purpose the investigator prepared self-made questionnaire. The finding shows that inflicting physical punishment creates pain, fear and feelings of humiliation and does not remove the cause of misbehavior. So the main thing is that discipline as a mean of punishment should be avoided and we should aim at making the child self-disciplined. Children should know how to discipline themselves and then grow up to become adults who are responsible i.e. able to carry on the important responsibilities of life.

Keywords: Attitude, Parents, Teachers, Students, Punishment

Man is the crown of creation. He is gifted with certain powers that we do not find in other living beings. Education is one of the powers that develops the individual like a flower to distribute its fragrance all over the environment.

In fact, India has a long history of organized education. The Gurukul system of education is one of the oldest on earth but before that the guru shishya system was extant, in which students were taught orally and the data would be passed from one generation to the next. As it is well said by will Durant that Education is the transmission of civilization.

\footnotetext{
${ }^{1}$ Associate Professor, Digamber Jain (PG) College Baraut, Baghpat (U.P)

${ }^{2}$ Assistant Teacher, P.S Belda Bujurg, Deoband Saharnapur

*Responding Author

(C) 2016 I M Muchhal, A Kumar; licensee IJIP. This is an Open Access Research distributed under the terms of the Creative Commons Attribution License (http://creativecommons.org/licenses/by/2.0), which permits unrestricted use, distribution, and reproduction in any Medium, provided the original work is properly cited.
} 
Gurukuls were traditional Hindu residential schools of learning; typically the teacher's house or a monastery. Education was free (and often limited to the higher castes), but students from well-todo families paid Gurudakshina, a voluntary contribution after the completion of their studies. At the Gurukuls, the teacher imparted knowledge of religion, scriptures, philosophy, literature, warfare, statecraft, mathematics, medicine, astrology and history. In this way destiny of future citizens chalked out by their Gurus. Although there were very strict and rigid rules to follow. During the time of education, the disciples were also punished for their indiscipline and misbehavior. But the punishment was only confined to do some physical work and had no adverse effect on the physical and mental abilities of the child.

As we are living in scientific era, there is no denying fact that education is an essential part of everyone's life. This is the reason our government is also becoming more and more conscious about education system and stressing on universalization of elementary education to make formal education system sound. But unfortunately, the formal education makes the child more and more unhappy and miserable as they are forcefully compelled to improve their intellectual, moral, ethical and social aspects of life. The reason behind this unhappiness is existence of corporal punishment in formal system of education.

\section{Present Scenario}

In the modern world, corporal punishment remains a common way of disciplining children; however its use has declined significantly since the 1950s. Race and gender have a significant influence on corporal punishment in the western world. Black children and male children are much more likely to be hit at home and school and corporal punishment of boys tends to be more severe, more frequent and more aggressive than corporal punishment administered to girls.

The aim of Indian education system is to provide child-centered education with love and affection. But the reality is far away as we see how students are being exploited by their teachers in formal system of education. Now-a-days, education is becoming completely mechanical and people are studying not for knowledge but for the sake of examination. They are giving more stress on memory work rather than reflective thinking. Similarly, teachers and parents are becoming more conscious about education of their children. Expectations are much higher than the ability of their child which sometimes lead to frustration on the part of parents and teachers and adopts the path of corporal punishment towards children.

\section{OBJECTIVES}

1. To study the attitude of teachers and parents towards corporal punishment.

2. To study the attitude of parents and students towards corporal punishment.

3. To study the attitude of teachers and students towards corporal punishment. 


\section{Hypotheses}

1. There is no significant difference in the attitude of teachers and parents towards corporal punishment.

2. There is no significant difference in the attitude of parents and students towards corporal punishment.

3. There is no significant difference in the attitude of teachers and students towards corporal punishment.

\section{Sample}

The present study aims to study the attitude of parents, teachers and students towards corporal punishment. For this purpose a total sample of 150 were selected on the bases of convenience sampling method. Then the investigator randomly selected 50 parents, 50 teachers and 50 students.

\section{Tool Used}

"Like the tools in the carpenter's box each research tool is appropriate in a given situation to accomplish a particular purpose. Each data gathering device has both merits and hazorels of limitations.”-BEST (1986)

The purpose of the present study was to judge the attitude of parents, teachers and students towards corporal punishment. For this purpose the investigator prepared self-made questionnaire to study the attitude of parents, teachers and students towards corporal punishment.

\section{RESULTS}

TABLE - 1, Means, S.D and t-ratios for the attitude of teachers and parents towards corporal punishment

\begin{tabular}{|l|l|l|l|l|l|l|}
\hline Groups & N & Mean & S.D. & S.E & t-ratio & $\begin{array}{l}\text { Level of } \\
\text { Significance }\end{array}$ \\
\hline Teachers & 50 & 136.76 & 11.35 & \multirow{2}{*}{2.15} & 3.66 & Significant at 0.01 \\
\cline { 1 - 4 } Parents & 50 & 144.64 & 10.22 & & \\
\hline
\end{tabular}

\section{Interpretation}

Table 1 shows that the calculated t-value is 3.66 which is more than the table value at .01 level. It reveals that there exists significant difference between the attitude of teachers and parents towards corporal punishment. Hence, the hypothesis framed earlier i.e. there is no significant difference between the attitude of teachers and parents towards corporal punishment stands rejected. It further shows that the mean scores of the teachers and parents on the attitude of corporal punishment are 136.76 and 144.64. It reveals that the parents showed more negative attitude towards corporal punishment as compared to the teachers. 
Bar diagram showing mean difference in the attitude of teachers and parents towards corporal punishment.



TABLE - 2, Means, S.D and t-ratios for the attitude of parents and students towards corporal punishment.

\begin{tabular}{|c|c|c|c|c|c|c|}
\hline Groups & $\mathbf{N}$ & Mean & S.D. & S.E. & t-ratio & $\begin{array}{l}\text { Level of } \\
\text { Significance }\end{array}$ \\
\hline Parents & 50 & 144.64 & 10.22 & \multirow{2}{*}{1.96} & \multirow{2}{*}{0.77} & \multirow{2}{*}{ Not Significant } \\
\hline Students & 50 & 146.16 & 9.49 & & & \\
\hline
\end{tabular}

\section{Interpretation}

Table 2 shows that the calculated t-value is 0.77 which is less than the table value at both .05 and .01 level. It reveals that there exists no significant difference between the attitude of parents and students towards corporal punishment. Hence, the hypothesis framed earlier i.e. there exists no significant difference between the attitude of parents and students towards corporal punishment stand accepted. It further shows that the mean scores of the parents and students on the attitude of corporal punishment are 144.64 and 146.16. It reveals that the students showed more negative attitude towards corporal punishment as compared to parents.

Bar diagram showing mean difference in the attitude of parents and students towards corporal punishment.

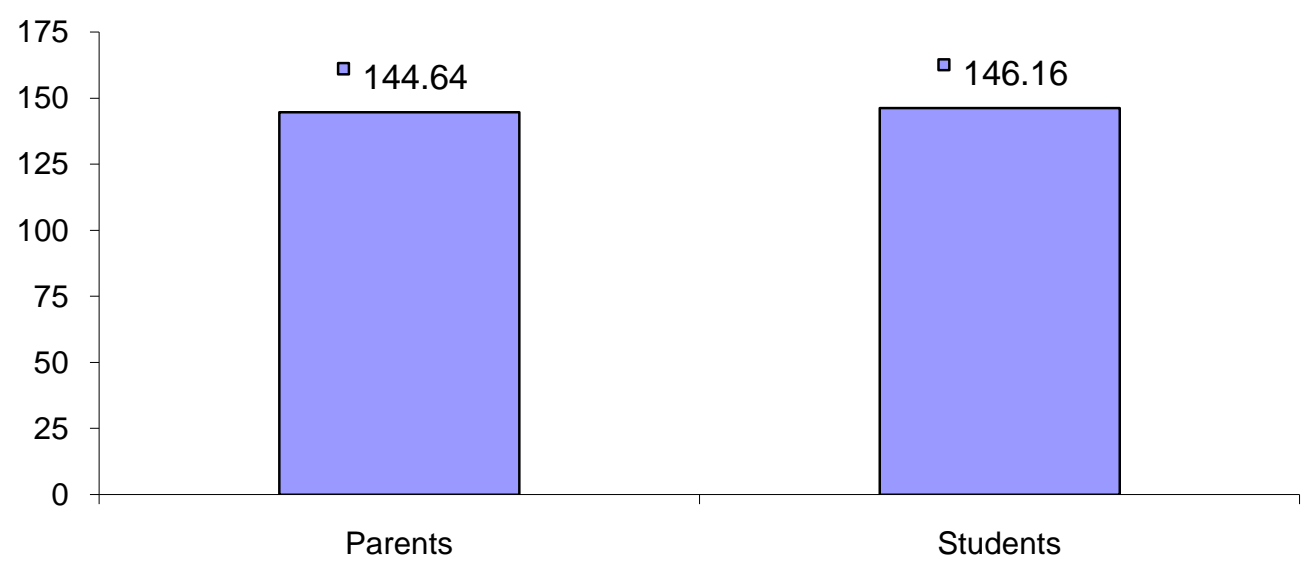


TABLE - 3, Means, S.D and t-ratios for the attitude of teachers and students towards corporal punishment.

\begin{tabular}{|c|c|c|c|c|c|c|}
\hline Groups & $\mathbf{N}$ & Mean & S.D. & S.E. & t-ratio & $\begin{array}{ll}\text { Level of } \\
\text { Significance }\end{array}$ \\
\hline Teachers & 50 & 136.76 & 11.35 & \multirow[t]{2}{*}{2.09} & \multirow[t]{2}{*}{4.49} & \multirow{2}{*}{$\begin{array}{l}\text { Significant } \\
0.01\end{array}$} \\
\hline Students & 50 & 146.16 & 9.49 & & & \\
\hline
\end{tabular}

\section{Interpretation}

Table 3 shows that the calculated t-value is 4.49 which is more than the table value at .01 level. It reveals that there exists significant difference in the attitude of teachers and students towards corporal punishment. Hence, the hypothesis framed earlier i.e. there exists no significant difference in the attitude of teachers and students towards corporal punishment stand rejected. It further shows that the mean of teachers and students towards corporal punishment are 136.76 and 146.16. It reveals that the students showed more negative attitude towards corporal punishment as compared to the teachers.

Bar diagram showing mean difference in the attitude of teachers and students towards corporal punishment.

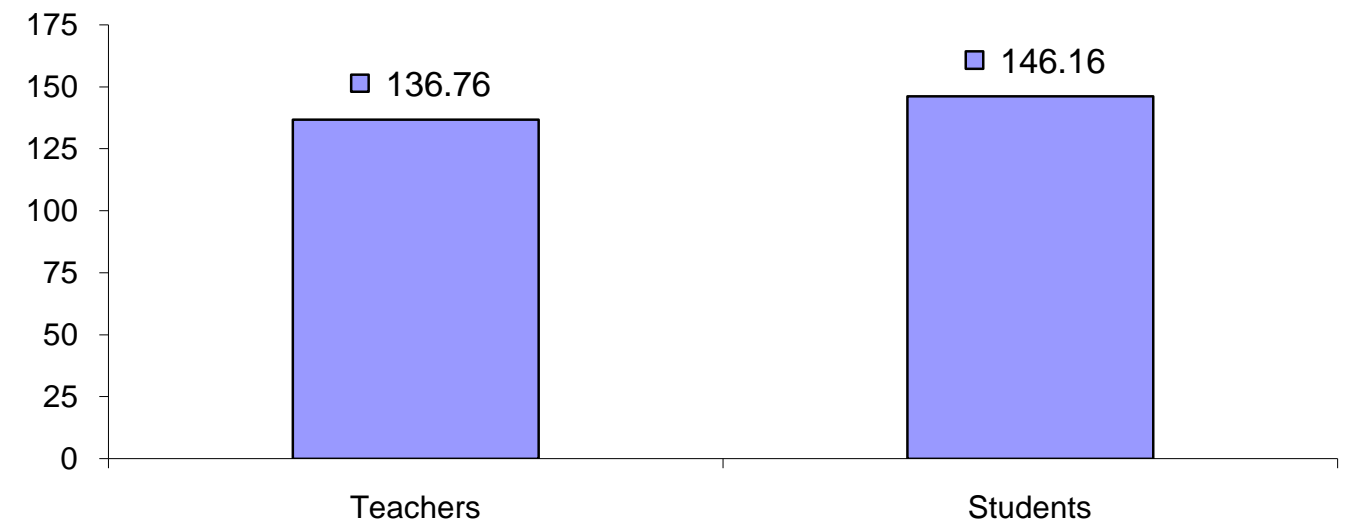

\section{CONTRIBUTION TO EDUCATION}

It is universally agreed that the quality of an educational programme is determined to a great extent by the teaching of a teacher. Above all, he is a "Karamyogi" who believes in purity of thought and action. Teachers play a key role in chalking out the destiny of future citizens. So teachers should adopt an approach which is tempered with love, care and understanding the child. The teacher should know that inflicting physical punishment creates pain, fear and feelings of humiliation and does not remove the cause of misbehavior. So the main thing is that discipline as a mean of punishment should be avoided and we should aim at making the child self- 


\section{Attitude of Parents, Teachers and Students towards Corporal Punishment}

disciplined. Children should know how to discipline themselves and then grow up to become adults who are responsible i.e. able to carry on the important responsibilities of life.

\section{BIBLIOGRAPHY}

Aggarwal, Y.P. (1983). Statistical Methods, Application and Computation. New Delhi: Sterling Publishers Pvt. Ltd..

Aggarwal, Y.P. (1998). The Science of Educational Research. Kurukshetra: Nirmal Book Agency.

Banerjee, N.P. (1993). Strategies of Educational Research. Ambala Cantt: The Association Publishers.

Best, J.W. and Kahn, James, V. (1986). Research in Education. New Delhi: Prentice Hall of India.

Buch, M.B. (1978). Second Survey of Research in Education. New Delhi: National Council of Educational Research And Training.

Buch, M.B. (1990-1992). Fifth Survey of Educational Research Vol-I. New Delhi: National Council of Educational Research And Training.

Buch, M.B. (1991). Fourth Survey of Research in Education. New Delhi: National Council of Educational Research And Training.

Garrett, H.F. (1981). Statistic in Psychology and Education. Bombay: Valkis, Feffer and Simons Ltd.

Guilford, J.P. (1956). Fundamental Statistics in Psychology and Education. Newyork: Mcgraw Hill Book Company.

Kohli, V.K. and Mathur, S.S. (1973). School Administration and Organization. Jalandhar City: Krishna Brothers, Chowk Tanda.

Koul, Lokesh (1984). Methodology of Educational Research. New Delhi: Vani Educational Books.

Sachdeva M.S. (1979). A Modern Approach to School Organization and Administration. Ludhiana: Prakash Brothers, Educational Publishers, (H.O.) 546, Books Market.

Sharma R.A. (1995). Fundamental of Educational Psychology. Meerut: R.Lal, 91 Book Depot.

\section{JOURANLS}

Edu Tracks Vol.4 ( March 2005). New Delhi: Neel Kamal Publications Pvt. Ltd.

Indian Psychological Review (2001). Vol-56 No. 1, Editor in Chief: Jai Prakash. Agra: Psychological Research Cell, Tiwari Kothi, Belanganj.

Indian Psychological Review (2001). Vol-56, No. 2, Editor in Chief: Jai Prakash, ibid.

Indian Psychological Review (2005). Vol-64, No. 3, Editor in Chief: Jai Prakash, ibid.

Journal of Southern African Studies( March 1997), Vol-23, No. 1, pp. 127-140, Published by Mbenga.

The Canadian Journal of Economics and Political Science (November 1938), Vol-4, No. 4 pp. 551-559, Editor in Chief: C.W.Topping.

\section{INTERNET RESOURCES}

www.crin.org/violence/search

www.expressindia.com

www.pib.nic.in/release 